Rev. Biol. Trop., 48(2/3): 657-664, 2000

www.ucr.ac.cr www.ots.ac.cr www.ots.duke.edu

\title{
Worker life tables, survivorship, and longevity in colonies of Bombus (Fervidobombus) atratus (Hymenoptera: Apidae)
}

\author{
Eunice Vieira da Silva-Matos and Carlos Alberto Garófalo \\ Departamento de Biologia, Faculdade de Filosofia, Ciências e Letras de Ribeirão Preto, USP, 14040-901, Ribeirão \\ Preto, SP, Brazil. Fax: (016) 602-3666. E-mail: garofalo@ffclrp.usp.br
}

Received 26-VIII-1999. Corrected 16-III-2000. Accepted 23-III-2000.

\begin{abstract}
Survivorship curves and longevity of workers were studied in two queenright and two queenless colonies of Bombus (Fervidobombus) atratus. Survivorship curves for workers of all colonies were, in general, convex, indicating an increasing mortality rate with increasing age. The mean longevity for the workers from queenright colonies, 24.3 days and 17.6 days, was not significantly different from that in queenless colonies, 21.2 days and 20.2 days. In all colonies workers started foraging activities when aged 0-5 days, and the potential forager rates rose progressively with increasing age. Mortality rates within each age interval were significantly correlated with the foraging worker rates in all colonies. Only in two of the colonies (one queenright and one queenless) longevity was significantly correlated with worker size. The duration of brood development period seems to be one of the most important factors influencing adult worker longevity in bumble bee species.
\end{abstract}

Key words: bumble bee, Bombus atratus, queenless colonies, survivorship curves, life table.

Although the longevity of individual workers is one of the most important factors in determining colony growth and reproductive rates in social insects (Wilson 1971, Winston 1979), information on this topic for bumble bee species is still very little. The few studies made have showed that the longevity of adult workers is variable among species, with the mean worker longevities for temperate species ranging from 13.2 days for Bombus terricola Kirby 1837 (Rodd et al. 1980) to 34.1 days for Bombus fervidus (Fabricius 1798) (Goldblat and Fell 1987) while for the only neotropical species up to now studied, Bombus morio (Swederus 1787), it is 41.3 days for all workers (Garófalo 1976). In addition to interspecific variation of longevity of bumble bee workers, some studies have showed that factors such as activities performed in the colony (Garófalo 1978, Katayama
1996), forage availability and phases in the colony development (Goldblat and Fell 1987) and colony conditions, if queenright or queenless colony (Katayama 1996) provide intraspecific variation in life expectancy of workers.

In the neotropical bumble bee, Bombus (Fervidobombus) atratus Franklin 1913, if the queen disappears or is removed from her colony, she is succeeded by a mated worker, the false queen, which produce. both female and male offspring and maintains colony development until the reproductive phase when new queens are produced (Zucchi 1973, Silva-Matos and Garófalo 1995). Silva-Matos and Garófalo (1995) showed that a new colony can be started from a group of queenless workers in the presence of some brood. In this case, the colony development is guaranteed by the appearance of a false queen, who takes over the queen's role. 
The aim of this study was to examine adult worker longevity in queenright $(\mathrm{QR})$ and queenless $(\mathrm{QL})$ colonies of $B$. atratus in order to verify if this bionomic character differs between the two types of colonies. In addition, these data help explain the differences observed in the longevity of temperate and tropical Bombus species.

\section{MATERIALS AND METHODS}

Two queenright colonies (QRC-1 and QRC-2) and two queenless colonies (QLC-1 and QLC-2) of B. atratus were studied. The colonies were maintained in unheated glasscovered wooden boxes $(28 \times 28 \times 8 \mathrm{~cm})$. The bees were allowed to freely leave the box through a plastic tube connecting the boxes to the outside through the laboratory wall. At the moment the observations were started the content of each colony was as follows: QRC-1 comprised a queen, 20 workers, 26 pupae, 26 larvae and six egg cells; QRC-2 consisted of a queen, 30 workers, 14 pupae, 12 larvae and five egg cells; QLC-1 was started with 45 newly emerged workers, 35 pupae, ten larvae and 14 egg cells removed from other colonies maintained in the laboratory; the largest worker present became the false queen and started to oviposit when she was ten days old and, QLC-2 was a queenright colony that became orphan due to the death of the queen; this colony comprised 87 workers, one larva and six egg cells, and the largest worker present replaced the queen; this worker had emerged in the presence of the queen and had started to oviposit when she was 26 days old.

Newly emerged bees were marked with numbered, plastic discs (Opalithplättchen) on the scutum, and their size was recorded (length of forewing from proximal portion of first $\mathrm{M}$ cell to distal end of radial cell). Of the workers produced in each colony, 626 from QRC-1, 634 from QRC-2, 798 from QLC-1 and 972 from QLC-2 were observed throughout their lives. Observations of the activities of the bees in the nests were carried out daily through the glass, usually between $0900 \mathrm{hr}$ and $1000 \mathrm{hr}$ and $1500 \mathrm{hr}$ and $1600 \mathrm{hr}$. Workers observed while ovipositing were not included in any cohort because they were removed from colonies and dissected to verify their spermathecal condition.

Age-specific life tables and survivorship curves were prepared using the methods of Sakagami and Fukuda (1968) and Rodd et al. (1980). The statistical tests are according to Zar (1984).

\section{RESULTS}

Queenright colonies produced 1605 (QRC1) and 639 (QRC-2) workers while in queenless colonies the number of workers produced was 798, in QLC-1, and 1 119, in QCL-2. There were no significant differences between the worker sizes from QLC and QRC (Scheffe's multiple contrast test; $p>0.05$ ) (Table 1).

No distinction between house-bees and foragers was made in either colony because all workers, except the egg-laying ones, were observed to forage, although some of them began foraging early than others. The mean longevity for the workers from QLC (QLC-1: $x=22.2 \pm$ 15.2 days, $\mathrm{n}=798$; $\mathrm{QLC}-2: \mathrm{x}=20.2 \pm 12.4$ days, $\mathrm{n}=972$ ) was not significantly different from those of $\mathrm{QRC}(\mathrm{QRC}-1: \mathrm{x}=24.3 \pm 9.15$ days, $\mathrm{n}=$ 626; $\mathrm{QRC}-2: \mathrm{x}=17.6 \pm 11.03$ days, $\mathrm{n}=$ 634)(Scheffe's multiple contrast test; $p>0.05$ ).

\section{TABLE 1}

Number and wing length of workers from two queenless and two queenrigth colonies of Bombus atratus

\begin{tabular}{lrcc} 
Colony & $\mathrm{n}$ & \multicolumn{2}{c}{ Wing length $(\mathrm{mm})$} \\
& & range & $\mathrm{x} \pm \mathrm{sd}$ \\
QLC-1 & 798 & $4.5-9.7$ & $7.61 \pm 0.85 \mathrm{a}^{1}$ \\
QLC-2 & 1119 & $4.9-9.5$ & $7.44 \pm 0.81 \mathrm{a}$ \\
QRC-1 & 1605 & $5.6-9.2$ & $7.46 \pm 0.61 \mathrm{a}$ \\
QRC-2 & 639 & $4.5-9.3$ & $7.59 \pm 0.94 \mathrm{a}$
\end{tabular}

1 Means followed by the same letter did not differ statistically (Scheffé's multiple contrasts test; $\mathrm{P}>0.05$ ) 
In all colonies some workers started foraging activities in the age interval 0-5 days. The age intervals when the percentage of living workers became less than $50.0 \%$ were 20 25 days, for QRC-1, 10-15 days, for QRC-2, and 15-20 days for both QLC. The greatest longevities were showed by some workers in QLC (Tables 2-5).

Survivorship curves for workers of all colonies were convex (Fig. 1), indicating an increasing mortality rate with increasing age. On the other hand, the curves were linear during the first 20 days in QLC, from 30 to 45 days, in QLC-1 and from 30 to 50 days in QLC-2, showing that in these age intervals, the workers experienced approximately constant mortality rates. In $\mathrm{QRC}$, however, the death rates rose progressively so that no linearity can be detected on the survivorship curves (Fig. 1).

TABLE 2

Life table for adult workers of Bombus atratus, $Q R C-1$

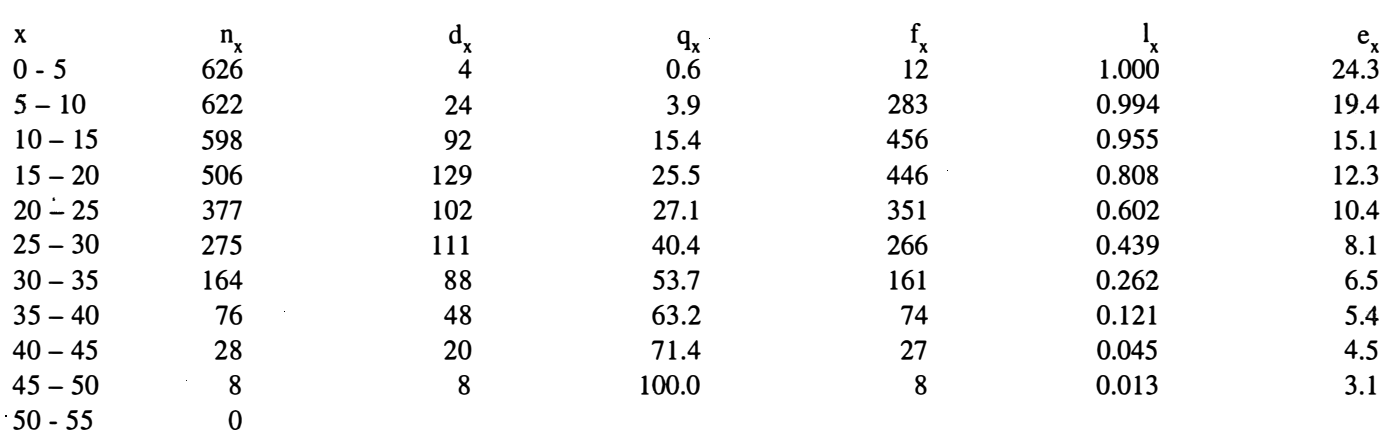

$x=$ start of age interval in days; $n_{x}=$ number alive at start of age interval; $d_{x}=$ number dying during age interval; $q_{x}=$ mortality rate during age interval; $f_{x}=$ number of potential foragers during age interval; $l_{x}=$ proportion surviving at start of age interval; $\mathrm{e}_{\mathrm{x}}=$ mean life span at the start of age interval.

\section{TABLE 3}

Life table for adult workers of Bombus atratus, $Q R C-2$

\begin{tabular}{|c|c|c|c|c|c|c|}
\hline $\mathrm{x}$ & $\mathrm{n}_{\mathrm{x}}$ & $d_{x}$ & $q_{x}$ & $\mathrm{f}_{\mathrm{x}}$ & $l_{x}$ & $e_{x}$ \\
\hline $0-5$ & 634 & 55 & 8.7 & 14 & 1.000 & 17.6 \\
\hline $5-10$ & 579 & 125 & 21.6 & 154 & 0.913 & 14.1 \\
\hline $10-15$ & 454 & 176 & 38.8 & 208 & 0.716 & 12.1 \\
\hline $15-20$ & 278 & 93 & 33.4 & 171 & 0.438 & 12.6 \\
\hline $20-25$ & 185 & 46 & 24.9 & 147 & 0.291 & 12.4 \\
\hline $25-30$ & 139 & 52 & 37.4 & 119 & 0.219 & 10.5 \\
\hline $30-35$ & 87 & 28 & 32.2 & 79 & 0.137 & 9.9 \\
\hline $35-40$ & 59 & 19 & 32.2 & 53 & 0.093 & 8.0 \\
\hline $40-45$ & 40 & 28 & 70.0 & 36 & 0.063 & 5.3 \\
\hline $45-50$ & 12 & 8 & 66.7 & 9 & 0.018 & 5.3 \\
\hline $50-55$ & 4 & 3 & 75.0 & 3 & 0.006 & 4.4 \\
\hline $55-60$ & 1 & 1 & 100.0 & 1 & 0.001 & 3.2 \\
\hline
\end{tabular}


TABLE 4

Life table for adult workers of Bombus atratus, QLC-1

$\begin{array}{lr}\mathrm{x} & \mathrm{n}_{\mathrm{x}} \\ 0-5 & 798 \\ 5-10 & 692 \\ 10-15 & 562 \\ 15-20 & 462 \\ 20-25 & 390 \\ 25-30 & 318 \\ 30-35 & 242 \\ 35-40 & 161 \\ 40-45 & 107 \\ 45-50 & 70 \\ 50-55 & 42 \\ 55-60 & 23 \\ 60-65 & 8 \\ 65-70 & 1 \\ 70-75 & 0\end{array}$

\section{$d_{x}$}

106

130

100

72

72

76

81

54

37

28

19

15

7 $q_{x}$

13.3

18.9

17.8

15.6

18.5

23.9

33.5

33.5

34.6

40.0

45.2

65.2

87.5

100.0

9
.3
8
.8
.6
.5
.9
.5
.6
.0
.2
.5
.0

$f_{x}$

$e_{x}$

22.2

20.2

19.2

17.7

15.4

13.2

11.5

10.7

9.7

8.2

6.7

4.9

3.6

2.9

TABLE 5

Life table for adult workers of Bombus atratus, QLC-2

$\begin{array}{lr}\mathrm{x} & \mathrm{n}_{\mathrm{x}} \\ 0-5 & 972 \\ 5-10 & 854 \\ 10-15 & 704 \\ 15-20 & 589 \\ 20-25 & 466 \\ 25-30 & 313 \\ 30-35 & 203 \\ 35-40 & 117 \\ 40-45 & 60 \\ 45-50 & 31 \\ 50-55 & 12 \\ 55-60 & 7 \\ 60-65 & 3 \\ 65-70 & 1 \\ 70-75 & 0\end{array}$

$d_{x}$
118
150
115
123
153
110
86
57
29
19
5
4
2
1

$\mathrm{q}_{\mathrm{x}}$
12.1
17.6
16.3
20.9
32.8
35.1
42.4
48.7
48.3
61.3
41.7
57.1
66.7
100.0

$f_{x}$

$e_{x}$

20.2

17.6

15.7

13.2

11.0

9.9

8.6

7.8

7.4

6.6

7.5

5.8

$\begin{array}{ll}0.003 & 4.6 \\ 0.001 & 2.9\end{array}$ 


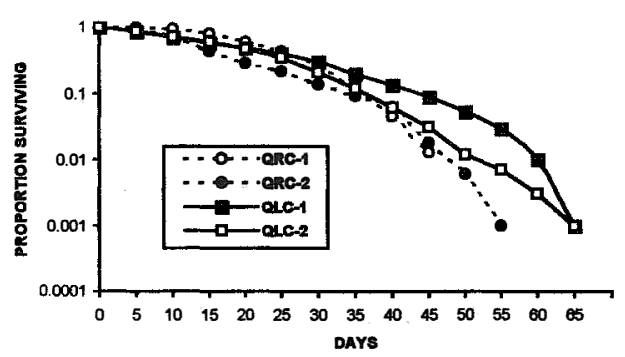

Fig. 1. Survivor curves for adult workers in queenright (QRC) and queenless (QLC) colonies of Bombus atratus.

In general, he potential forager rates within each colony rose progressively with increasing age (Fig. 2), but some differences were observed among colonies. In QRC-1, the percentage of potential foragers within each age interval was always higher than in all other colonies. In QLC-2, on the contrary, the percentage of potential foragers was always lower than those in all colonies up to the age interval 35-40 days; afterwards, the percentage was similar to that of QLC-1, from 40 to 55 days, decreasing in the following two intervals. On the other hand, the curves of potential foragers in QRC-2 and QLC-1 were similar up to the age interval 40-45 days; after that, the foraging population of QRC-2 was lower than that of QLC-1 (Fig. 2).

In all colonies, mortality rates within each age interval were significantly correlated with the foraging worker rates $(\mathrm{QRC}-1: \mathrm{r}=0.71$; QRC-2: $\mathrm{r}=0.61$; QLC-1: $\mathrm{r}=0.57$; QLC-2: $\mathrm{r}=$ $0.78 ; \mathrm{p}<0.05$ in all cases).

In QRC-2 and QLC-1, longevity was significantly correlated with worker size (QRC-2: $\mathrm{r}=0.15$; QLC-1: $\mathrm{r}=0.12 ; \mathrm{P}<0.005$ in both cases) but in QRC-1 and QLC-2 no significant correlation between those parameters was found (QRC-1: $r=-0.008$; QLC-2 $\mathrm{r}=-0.050$; $\mathrm{p}>0.05$ in both cases).

\section{DISCUSSION}

The data presented in this study indicate that in $B$. atratus, the size of produced workers



Fig. 2. Percent of fraging workers in each age interval in queenright (QRC) and queenless (QLC) colonies of Bombus atratus.

and the mean longevity of them were not affected by colony conditions, if queenright or queenless. These bionomic similarities observed between the colonies occur because in QLC the false queen takes over the queen's role and guarantees the colony development (SilvaMatos and Garófalo 1995). In Bombus diversus Smith 1869, however, workers in QLC showed an average longevity longer than that in QRC. This, according to Katayama (1996), was provided by the low foraging activity since after the death of the queen most workers tended to stay in the nest to obtain the position of predominant egg-layer. As the bees that remain in the nest have significantly lower rates of mortality than foragers (Alford 1975, Garófalo 1978, Katayama 1996), the results reported by Katayama (1996) are not surprising.

Many factors can influence adult worker longevity for social bees. Among the bumble bee species one of these factors is the worker size. Foragers, which are among the largest bees in the colony, have a shorter life-span than the house-bees (Brian 1952, Garófalo 1978, Katayama 1996), which remain on the nest and tend to be small (Richards 1946, Cumber 1949, Brian 1952, Free 1955, Sakagami and Zucchi 1965, Garófalo 1978, Pouvreau 1989). So, as reported by Garofalo (1978), for B. morio, and Goldblat and Fell (1987), for B. fervidus and Bombus pennsylvanicus (DeGeer 1773), large worker size was associated with a reduced longevity. The results obtained in this study showed no association between worker size and longevity in QRC-1 and QLC-2 while in QRC-2 
and QLC-1, large worker size was associated with an increased longevity. However, the low correlation coefficient values found indicate a weak association between those parameters. This, probably, was due to absence of a clear distinction between house-bees and foragers since all workers performed to a greater or lesser extent all tasks in the colonies.

Another factor related with adult worker longevity is the age at which workers begin foraging since this activity exposes the workers to several extranidal hazards. As observed in this study, some workers started foraging in the age interval 0-5 days after emergence. Similar observations have been reported by Garófalo (1978), for B. morio, ValenzuelaGonzález (1981), for Bombus pascuorum (Scopoli 1763) and Bombus lapidarius (Linnaeus 1758), Pouvreau (1989), for Bombus lucorum (Linnaeus 1761), B. pascuorum and B. lapidarius, and Katayama (1996), for Bombus ardens Smith 1879 and B. diversus. Given that when workers begin leaving the nest to go on foraging trips they also start perishing at a very high rate, the early participation in foraging, as observed in Bombus species, must result in a rapid decline of the survivorship curve in early adult life (Katayama 1996).

As reported in all previously studied bumble bee species (Brian 1952, Garófalo 1978, Rodd et al. 1980, Goldblat and Fell 1987, Katayama 1996), the survivorship curves for all colonies observed in this study were convex. The survivorship curves of QLC, however, were slightly more convex than those of QRC. This was mainly due to occurrence of constant mortality rates during the early age intervals in both QLC, with subsequent convexity representing mortality increased with age. Goldblat and Fell (1987) reported similar observations for $B$. pennsylvanicus and $B$. fervidus colonies.

In general, the mean longevity for workers of $B$. atratus was higher than those found for B. terricola (13.2 days) (Rodd et al. 1980), Bombus humilis (Illinger 1806) (17.5 days) (A.D. Brian, unpublished, cited in Brian 1965) and $B$. diversus (19.4 days) (Katayama 1996), similar or lower than those for B. fervidus (21.8 days, for one colony, and 34.1 days, for another colony), $B$. pennsylvanicus (33.0 days) (Goldblatt and Fell 1987) and B. ardens (26.3 days) (Katayama 1996), and considerably lower than those for B. morio (41.3 days, for all workers, irrespective of activities performed in the colony (Garófalo 1976), 72.6 days, 69.7 days and 36.4 days for house-bees, foragers/house-bees and foragers, respectively (Garófalo 1978).

Rodd et al. (1980) have suggested that the variation in the longevity among species is related to the colony growth rate which depends upon of the duration of the egg-toadult developmental period. Slower growing colonies have workers allocating less time for brood clump provisioning and therefore they would be exposed to reduced mortality risk. In addition to a reduction in the daily risk of predation and other environmental hazards, less time spent foraging per day would result in a longer potential foraging period before exhaustion of a flight performance limit (Goldblat and Fell 1987). A comparison between $B$. morio and $B$. atratus shows that the former has a longer egg-to-adult period (about 32 days for workers, 35 days for males and 39 days for queens (Garófalo 1976)) than does B. atratus (about 28 days for workers (Sakagami et al. 1967), 30 days for males and 32 days for queens (Zucchi 1973)) and that its colonies grow more slowly than those of $B$. atratus (C.A.Garófalo and E.V. Silva-Matos, unpublished). The differences observed between immature and adult longevity would strengthen Rodd et al. (1980) arguments. Similarly, the significant difference found in the mean growth rates of $B$. atratus and $B$. terricola colonies (Laverty and Plowright 1985) could also explain the highest mean longevity for $B$. atratus workers. Interestingly, the data reported by Katayama $(1966,1996)$ for $B$. diversus reinforce the relation the shorter the duration of brood development (22-24 days), the shorter the mean longevity of workers (19.4 days). 


\section{ACKNOWLEDGEMENTS}

We are grateful to Gerson Muccillo for the statistical analysis. E.V. Silva-Matos received a grant from Coordenadoria de Aperfeiçoamento de Pessoal de Nível Superior (CAPES).

\section{REFERENCES}

Alford, D.V. 1975. Bumblebees. Davis-Poynter, London. 352 p.

Brian, A.D. 1952. Division of labor and foraging in Bombus agrorum Fabricius. J. Anim. Ecol. 21:223-240.

Brian, M.V. 1965. Social insects population. Academic, London. $135 \mathrm{p}$.

Cumber, R.A. 1949. Biology of humble-bees with special reference to the production of the worker caste. Trans. R. ent. Soc. Lond. 100: 1-45.

Free, J.B. 1955. The division of labour within bumblebee colonies. Ins. Soc. 2: 195-212.

Garófalo, C.A. 1976. Evolução do comportamento social visualizada através da ecologia de Bombus morio (Hymenoptera, Bombinae). PhD thesis, Universidade de São Paulo, Ribeirão Preto, Brasil.

Garófalo, C.A. 1978. Bionomics of Bombus (Fervidobombus) morio. II. Body size and length of workers. J. Apic. Res. 17:130-136.

Goldblat, J.W. \& R. D. Fell. 1987. Adult longevity of workers of the bumble bees Bombus fervidus (F.) and Bombus pennsylvanicus (De Geer) (Hymenoptera: Apidae). Can. J. Zool. 65: 2349-2353.

Katayama, E. 1966. Studies on the development of the brood of Bombus diversus Smith (Hymenoptera, Apidae). II. Brood development and feeding habits. Kontyû 34:8-17.

Katayama, E. 1996. Survivorship curves and longevity for workers of Bombus ardens Smith and Bombus diversus Smith (Hymenoptera, Apidae). Jpn. J. Ent. 64:111-121.

Laverty, T.M. \& R.C. Plowright. 1985. Comparative bionomics of temperate and tropical bumble bees with special reference to Bombus ephippiatus (Hymenoptera, Apidae). Can. Ent. 117: 467-474.
Pouvreau, A. 1989. Contribution à l'étude du polyéthisme chez les bourdons, Bombus Latr. (Hymenoptera, Apidae). Apidologie 20: 229-244.

Richards, O. W. 1946. Observations on Bombus agrorum (Fabricius)(Hymen., Bombidae). Proc. R. ent. Soc. Lond. 21: 66-71.

Rodd, F.H., R.C. Plowright \& R. E. Owen. 1980. Mortality rates of adult bumble bee workers (Hymenoptera, Apidae). Can. J. Zool. 58: 1718-1721.

Sakagami, S.F. \& R. Zucchi. 1965. Winterverhalten einer neotropischen Hummel, Bombus atratus, innerhalb des Beobachtungskasten. Ein Beitrag zur Biologie der Hummeln. J. Fac. Sci. Hokkaido Univ. (VI Zool.) 15: 712-762.

Sakagami, S.F. \& H. Fukuda. 1968. Life tables for worker honeybees. Res. Popul. Ecol. 10: 127-139.

Sakagami, S.F., Y. Akahira \& R. Zucchi. 1967. Nest architecture and brood development in a neotropical bumblebee, Bombus atratus. Ins. Soc. 14: 389-413.

Silva-Matos, E.V. \& C.A. Garófalo. 1995. Observations on the development of queenless colonies of Bombus atratus (Hymenoptera, Apidae). J. Apic. Res. 34: 177-185.

Valenzuela-Gonzálvez, J.E. 1981. Contribucion al estudio de la division del trabajo en los abejorros: Bombus pascuorum (Linneo) y B. lapidarius (Scopoli) (Hymenoptera, Apoidea). Folia Entomol. Mexicana 49: 121-139.

Wilson, E.O. 1971. Insect societies. Harvard University, Cambridge, Massachussetts. 548 p.

Winston, M.L. 1979. Intra-colony demography and reproductive rate of the africanized honeybee in South America. Behav. Ecol. Sociobiol. 4: 279-292.

Zar. J.H. 1984. Biostatistical analysis. Prentice-Hall, Inglewood Cliffs, New Jersey. 718 p.

Zucchi, R. 1973. Aspectos bionômicos de Exomalopsis aureopilosa e Bombus atratus incluindo considerações sobre a evolução do comportamento social (Hymenoptera, Apoidea). Ph.D. Thesis, Faculdade de Filosofia, Ciências e Letras de Ribeirão Preto, São Paulo, Brasil. 